\title{
Two fatty acid anion-based ionic liquids - Part I: Physicochemical properties and tribological behavior as neat lubricants
}

\author{
M. Sernagliaa ${ }^{\mathrm{a}}$ D. Blanco ${ }^{\mathrm{b}}$, A. Hernández Battez ${ }^{\mathrm{b}, \mathrm{c}}$ \\ J.L. Viesca ${ }^{\mathrm{b}, \mathrm{c}}$, R. González ${ }^{\mathrm{a}, \mathrm{c}}$, M. Bartoloméa \\ ${ }^{a}$ Department of Marine Science and Technology, University of Oviedo, Asturias, Spain \\ ${ }^{\mathrm{b}}$ Department of Construction and Manufacturing Engineering, University of Oviedo, Asturias, Spain \\ c Department of Design and Engineering, Bournemouth University, Poole, BH12 5BB, UK \\ ${ }^{(*)}$ Email: blancoadavid@,uniovi.es
}

\begin{abstract}
Two new ionic liquids ( $\left[\mathrm{N}_{6,6,6,6}\right]\left[\mathrm{C}_{8: 0}\right]$ and $\left.\left[\mathrm{N}_{6,6,6,6}\right]\left[\mathrm{C}_{16: 0}\right]\right)$ synthetized from fatty acids through a salt metathesis reaction were both characterized from a physicochemical and tribological point of view. Density, viscosity, corrosion activity and thermal stability tests were performed before making tribological tests under ball-on-disc both unidirectional (with fixed and variable slide-to-roll ratio) and reciprocating configuration. The main results of this work were the following: the longer the length of the alkyl chain of the anion the lower both viscosity and density and higher both viscosity index and thermal stability; these ionic liquids (ILs) are not corrosive; the $\left[\mathrm{N}_{6,6,6,6}\right]\left[\mathrm{C}_{16: 0}\right]$ behaved better changing from elastohydrodynamic to mixed lubrication regime at lower speeds; their antiwear behavior at high load seems depend on their viscosity (for tests made at room temperature) and thermal stability and IL-surface interaction (for tests made at high temperature).
\end{abstract}

Keywords: ionic liquids; fatty acids; lubrication; physicochemical properties; friction; wear

\section{Introduction}

The importance of lubrication in industrial engineering applications is a widely considered issue in Tribology [1-3]. Although lubrication science is usually focused on reducing friction, minimizing wear, evacuating heat and removing contaminants, the main struggle in this research area nowadays is the continuous search for both improving efficiency and developing greener lubricants. This fact is mainly related to the greater awareness of the pollutant effects on the environment of the human activity $[4,5]$.

The study of using ionic liquids (ILs) as lubricants began almost two decades ago because of their remarkable characteristics, such as negligible vapour pressure, non-flammability, electrical conductivity, inherent polarity and excellent thermal and oxidative stability, which making them feasible to be included in lubricant formulation [6-14]. ILs have demonstrated excellent lubricant properties, especially related to the ability to form tribofilms on the contact surfaces that result in a reduction of friction and wear [15-29]. However, the most of ILs synthetized until now are constituted by some elements that are toxic or hazardous to the environment [30-39].

Although natural oils are largely used as lubricants since the beginning of lubrication, utilisation of biobased lubricants is rising [40-46]. The enormous possibilities of synthetizing ILs through the combination of existing ions lead to the obtention of new environmentally friendly compounds that improve 
biodegradability and non-toxic characteristics contributing to a more sustainable development [47]. One of these novel compounds are fatty acids anion-based ionic liquids (FAILs) and their obtention via metathesis was reported for the first time in 2013 [48]. Since then, some researches regarding the feasibility of using these substances in lubrication have been published [49-56].

This work deals with the physicochemical and tribological characterization of two new ionic liquids (tetrahexylammonium octanoate and tetrahexylammonium hexadecanoate) synthetized through a salt metathesis reaction with the aim of using them in lubrication.

\section{Experimental details}

\subsection{Chemicals}

In order to carry out the synthesis of the fatty acid ionic liquids (FAILs), some reagents were used: tetrahexylammonium bromide ionic liquid $\left(\left[\mathrm{N}_{6,6,6,6}\right][\mathrm{Br}]\right)(\geq 99 \%)$, octanoic and hexadecanoic acids (natural $\geq 98 \%$ ) as cation and anion precursor, respectively; ethanol solution $(70 \% \mathrm{w} / \mathrm{w})$, sodium hydroxide and toluene (99.8\%). These chemical substances were supplied by Sigma-Aldrich S.A and employed without any further purification.

\subsection{Synthesis of FAILs}

A couple of novel FAILs: tetrahexylammonium octanoate $\left(\left[\mathrm{N}_{6,6,6,6}\right]\left[\mathrm{C}_{8: 0}\right]\right)$ and tetrahexylammonium hexadecanoate $\left(\left[\mathrm{N}_{6,6,6,6}\right]\left[\mathrm{C}_{16: 0}\right]\right)$ were obtained from natural sources via synthesis using a known salt metathesis reaction. This chemical procedure starts with the ester formation, mixing 25 mmol of sodium hydroxide (aqueous solution) with $25 \mathrm{mmol}$ of the selected fatty acid (ethanol solution). The resulting mixture was stirred at $800 \mathrm{rpm}$ for $12 \mathrm{~h}$. In order to obtain the expected ester, the organic solvent is eliminated in a rotary evaporator by vacuum distillation and the water is removed in a temperature fixed oven $\left(65^{\circ} \mathrm{C}\right)$. This purification step should be ended when the product reaches the stoichiometric weight. The synthesis continues with the double replacement reaction: the ester obtained in the previous step was dissolved again (aqueous medium) and blended with an organic phase of $25 \mathrm{mmol}$ of tetrahexylammonium bromide (toluene medium). The 2 phases-mixture was left $24 \mathrm{~h}$ under continuous stirring at $800 \mathrm{rpm}$. The organic phase should contain the objective FAIL synthetized, which will be purified using several ultrapure water washes after the removal of the water phase. Finally, the solvent of the purified organic phase will be removed in a rotary evaporator by vacuum distillation obtaining a bright orange liquid product (ionic liquid) with the yield ranging $85-95 \%$. 


\subsection{Identification of FAILs}

${ }^{1} \mathrm{H}$ and ${ }^{13} \mathrm{C}$ NMR analyses, besides the FTIR spectra, were carried out with the aim of confirming the molecular structures of the two synthesized FAILs. A Bruker AV600 nuclear magnetic resonance spectrometer (NMR) were used to obtain both NMR spectra, using $\mathrm{CDCl}_{3}$ as solvent. The resonance frequencies for ${ }^{1} \mathrm{H}$ and ${ }^{13} \mathrm{C}$ NMR were 600.15 and $150.92 \mathrm{MHz}$, respectively. Fourier transform Infrared spectra (FTIR) of the FAILs were obtained in a Varian 670-IR FTIR spectrometer, using 16 scans, 600$4000 \mathrm{~cm}^{-1}$ operation range and $4 \mathrm{~cm}^{-1}$ resolution.

\subsection{Density, viscosity and thermal properties}

A Stabinger Viscometer SVM3001 equipment was employed to measure density and dynamic viscosity of the FAILs. Measurements were carried out according to ASTM D7042 at atmospheric pressure and temperature from 20 to $100{ }^{\circ} \mathrm{C}$. Kinematic viscosity and viscosity index (VI) were calculated from the previous results following the ASTM D2270-04. Thermogravimetric analysis (TGA) of both FAILs were carried out using a DSC/SDT Q600 TA Instruments equipment. Dynamic scans were conducted employing a sample of about $6 \mathrm{mg}$, from 25 to $600{ }^{\circ} \mathrm{C}$ and using a $10^{\circ} \mathrm{C} / \mathrm{min}$ heating rate under an oxygen atmosphere of $50 \mathrm{~mL} / \mathrm{min}$ of flow rate.

\subsection{Corrosion behavior}

A couple of straightforward tests were conducted in order to analyze the corrosion activity of the FAILs. Both ionic liquids studied were applied separately on AISI 52100 steel surfaces used in this work keeping them at room temperature in air for two different exposure times: a) 20 days and b) 365 days [57,58]. All surfaces were previously cleaned with heptane in an ultrasonic bath and air dried. In addition, corrosion tests were also conducted for both ILs during $24 \mathrm{~h}$ at $100^{\circ} \mathrm{C}$ with the aim of avoiding humidity issues. Afterward, all AISI 52100 steel surfaces were cleaned with heptane and air dried and then analyzed by scanning electron microscopy (SEM) and energy dispersive spectroscopy (EDS).

\subsection{Tribological tests}

This section could be divided in 2 different stages performed in two different tribometers. In the first stage, a Mini Traction Machine tribometer (PCS Instruments) was used to study the lubrication behavior of the FAILs under different lubrication regimes. Firstly, a ball-on-disc configuration at $50 \%$ of slide-to-roll ratio (SRR) was used with the following test conditions: mean entrainment speed between 2500 and $10 \mathrm{~mm} \cdot \mathrm{s}^{-1}$ (steps of $100 \mathrm{~mm} \cdot \mathrm{s}^{-1}$ from 2500 to 100 and steps of $10 \mathrm{~mm} \cdot \mathrm{s}^{-1}$ from 100 to 10 ), at $30 \mathrm{~N}$-load (equivalent 
to $0.95 \mathrm{GPa}$ of maximum contact pressure), temperature of $40,60,80$, and $100{ }^{\circ} \mathrm{C}$, and a lubricant volume of $10 \mathrm{~mL}$. Secondly, tests at increasing SRR values (5-50\%) were performed at a rolling speed of 2000 $\mathrm{mm} \cdot \mathrm{s}^{-1}$ and at the same load and temperatures than that used firstly.

The average velocity or mean entrainment speed can be determined used Eq. (1), where $u_{d}$ and $u_{b}$ are the velocity of the disk and the ball at the point of contact, respectively. Finally, the slide-to-roll ratio (SRR) was calculated using Eq. (2), being $\left(u_{d}-u_{b}\right)$ the sliding speed.

$$
\begin{gathered}
u_{m}=\frac{u_{d}+u_{b}}{2} \\
\operatorname{SRR}(\%)=\frac{2\left(u_{d}-u_{b}\right)}{\left(u_{d}+u_{b}\right)} \times 100
\end{gathered}
$$

Coefficient of friction and ECR (electrical contact resistance) were determined during the tests and the socalled Stribeck curve was obtained, allowing to study the lubricant behavior of the FAILs under boundary and mixed lubrication regimes. Before each test, the specimens (balls and discs) were ultrasonically cleaned in heptane for $10 \mathrm{~min}$, then rinsed in ethanol and dried in hot air. A description of the specimens used in these tests is included in Table 1.

The second stage involves the use of a UMT-3 tribometer (Bruker Corporation) with a reciprocating ballon-disc configuration. Two temperatures $\left(25\right.$ and $100^{\circ} \mathrm{C}$ ) and three different loads: $10 \mathrm{~N}$ (or $1.43 \mathrm{GPa}$ of maximum contact pressure), $30 \mathrm{~N}$ (or $2.06 \mathrm{GPa}$ of maximum contact pressure) and $50 \mathrm{~N}$ (or $2.43 \mathrm{GPa}$ of maximum contact pressure) were employed in the tribological tests. The rest of tests conditions were the following: $15 \mathrm{~Hz}$ frequency, $4 \mathrm{~mm}$ of stroke length, relative humidity in the range $40-60 \%$ and $4 \mathrm{~mL}$ of lubricant sample. The test duration was $30 \mathrm{~min}$ and three replicates were done with a relative error lower than $10 \%$ in all cases. The coefficient of friction $(\mathrm{COF})$ was measured during the assay and the wear volume on the disc surface was measured after testing using a Leica DCM 3D confocal microscope. Table 1 shows the description of the specimens employed to conduct all tribological tests. The specimens were cleaned following the same procedure used with the MTM specimens.

Finally, scanning electron microscopy (SEM) and energy dispersive spectroscopy (EDS) were employed in order to assess the chemical interaction of the FAILs with the surface. The equipment used for this purpose was a JEOL-6610-LV SEM with tungsten filament electron gun working at $20 \mathrm{kV}$ of acceleration voltage, secondary electron detector and a maximum resolution of $3.0 \mathrm{~nm}$ from 5 to 50000 increases. In addition, EDS microanalysis equipment has an SDD detector with linear resolution of $125 \mathrm{eV}$ in $\mathrm{Mn} \mathrm{K} \alpha$ from 1 to $20000 \mathrm{cps}$ and active area of $50 \mathrm{~mm}^{2}$ integrated in the microscope. An Oxford INCA Complete 
integrated software allows to select points or areas on the microscopic image for analysis and the ultra-thin window allows the detection and quantification of ultralights elements of $(\mathrm{C}, \mathrm{N}, \mathrm{O} \ldots)$.

Table 1 Main properties of the specimens used in tribological tests.

\begin{tabular}{|c|c|c|c|c|c|c|}
\hline \multirow{3}{*}{ AISI 52100 steel } & \multicolumn{6}{|c|}{ Chemical composition (\%) } \\
\hline & $\mathrm{C}$ & $\mathrm{Si}$ & $\mathrm{Mn}$ & $\mathrm{Cr}$ & $\mathrm{P}$ & $\mathrm{S}$ \\
\hline & $0.98-1.1$ & $0.15-0.30$ & $0.25-0.45$ & $1.30-1.60$ & 0.025 & 0.025 \\
\hline \multicolumn{2}{|c|}{ Specimens } & Dimensions & \multicolumn{2}{|c|}{ Hardness } & \multicolumn{2}{|c|}{ Roughness (Ra) } \\
\hline \multirow[t]{2}{*}{ MTM } & Disks & $\begin{array}{l}46 \mathrm{~mm} \text { diameter } \\
\text { x } 5 \mathrm{~mm} \text { thick }\end{array}$ & \multicolumn{2}{|c|}{$720-780 \mathrm{HV}_{30}$} & \multicolumn{2}{|c|}{$<0.02 \mu \mathrm{m}$} \\
\hline & Balls & $19.05 \mathrm{~mm}$ diameter & \multicolumn{2}{|c|}{$800-920 \mathrm{HV}_{30}$} & \multicolumn{2}{|c|}{$<0.02 \mu \mathrm{m}$} \\
\hline \multirow[t]{2}{*}{ UMT } & Disks & $\begin{array}{l}10 \mathrm{~mm} \text { diameter } \\
\times 3 \mathrm{~mm} \text { thick }\end{array}$ & \multicolumn{2}{|c|}{$225 \mathrm{HV}_{30}$} & \multicolumn{2}{|c|}{$0.018 \mu \mathrm{m}$} \\
\hline & Balls & $6 \mathrm{~mm}$ diameter & \multicolumn{2}{|c|}{ 58-66 HRC } & \multicolumn{2}{|c|}{$0.05 \mu \mathrm{m}$} \\
\hline
\end{tabular}

\section{Results and discussion}

\subsection{Identification of the FAILs}

\subsubsection{NMR}

${ }^{1} \mathrm{H}$ and ${ }^{13} \mathrm{C}$ NMR analyses confirmed the chemical structure of the FAILs. The chemical shifts of ${ }^{1} \mathrm{H}$ NMR and ${ }^{13} \mathrm{C}$ NMR along with their assignments are shown below:

$\left[\mathbf{N}_{6,6,6,6}\right]\left[\mathbf{C}_{8: 0}\right]$

${ }^{1} \mathrm{HNMR}\left(600 \mathrm{MHz}, \mathrm{CDCl} \mathrm{N}_{3} \delta(\mathrm{ppm}): 3.3\left(\mathrm{~m}, 8 \mathrm{H},-\mathrm{N}-\mathrm{CH}_{2}\right), 2.14\left(\mathrm{t}, 2 \mathrm{H},-\mathrm{CH}_{2} \mathrm{COO}\right), 1.62\left(\mathrm{~m}, 10 \mathrm{H},-\mathrm{CH}_{2}-\right.\right.$ $\left.\mathrm{N} /-\mathrm{CH}_{2}-\mathrm{O}\right), 1.2-1.4\left(\mathrm{~m}, 32 \mathrm{H},-\mathrm{CH}_{2}\right), 0.8-0.9\left(\mathrm{~m}, 15 \mathrm{H},-\mathrm{CH}_{3}\right)$.

${ }^{13} \mathrm{C} \mathrm{NMR}\left(150 \mathrm{MHz}, \mathrm{CDCl}_{3}\right) \delta(\mathrm{ppm}): 179.3(1 \mathrm{C},-\mathrm{COO}), 58.96\left(4 \mathrm{C},-\mathrm{CH}_{2}-\mathrm{N}\right), 39.32\left(1 \mathrm{C},-\mathrm{CH}_{2} \mathrm{COO}\right)$, 26.03-31.93 (16C,. $\left.\mathrm{CH}_{2}\right), 22.1-22.7\left(5 \mathrm{C},-\mathrm{CH}_{2}-\mathrm{N} /-\mathrm{CH}_{2}-\mathrm{O}\right), 13.84-14.08\left(5 \mathrm{C},-\mathrm{CH}_{3}\right)$.

$\left[\mathbf{N}_{6,6,6,6}\right]\left[\mathbf{C}_{16: 0}\right]$

${ }^{1} \mathrm{H} \mathrm{NMR}(600 \mathrm{MHz}, \mathrm{CDCl} 3) \delta(\mathrm{ppm}): 3.34\left(\mathrm{~m}, 8 \mathrm{H},-\mathrm{N}-\mathrm{CH}_{2}\right), 2.15\left(\mathrm{t}, 2 \mathrm{H},-\mathrm{CH}_{2} \mathrm{COO}\right), 1.61\left(\mathrm{~m}, 10 \mathrm{H},-\mathrm{CH}_{2}\right.$ $\left.-\mathrm{N} /-\mathrm{CH}_{2}-\mathrm{O}\right), 1.19-1.39\left(\mathrm{~m}, 48 \mathrm{H},-\mathrm{CH}_{2}\right), 0.82-0.88\left(\mathrm{~m}, 15 \mathrm{H},-\mathrm{CH}_{3}\right)$.

${ }^{13} \mathrm{C} \mathrm{NMR}\left(150 \mathrm{MHz}, \mathrm{CDCl}_{3}\right) \delta(\mathrm{ppm}): 179.06(1 \mathrm{C},-\mathrm{COO}), 58.94\left(4 \mathrm{C},-\mathrm{CH}_{2}-\mathrm{N}\right), 39.11\left(1 \mathrm{C},-\mathrm{CH}_{2} \mathrm{COO}\right)$, 26.06-31.88 (24C, . $\left.\mathrm{CH}_{2}\right), 22.14-22.65\left(5 \mathrm{C},-\mathrm{CH}_{2}-\mathrm{N} /-\mathrm{CH}_{2}-\mathrm{O}\right), 13.84-14.07\left(5 \mathrm{C},-\mathrm{CH}_{3}\right)$.

Analyzing both ${ }^{1} \mathrm{H}$ NMR and ${ }^{13} \mathrm{C}$ NMR spectra, the terminal methyl group $\left(-\mathrm{CH}_{3}\right)$ of tetrahexylammonium cation and both octanoic and hexadecanoic fatty acid-based anions showed chemical shift in the range of 0.8-0.9 ppm and 13.84-14.08 ppm, respectively. The chemical shifts at $1.19-1.39 \mathrm{ppm}\left({ }^{1} \mathrm{H}\right)$ and $26.06-$ $31.88\left({ }^{13} \mathrm{C}\right)$ were attributed to the shielded methylene units $\left(-\mathrm{CH}_{2}\right)$ in both cation and anion. The methylene 
group at intermediate position, close to the electronegative atoms $(\mathrm{N}$ or $\mathrm{O})$, showed chemical shifts at 1.61$1.62 \mathrm{ppm}$ or 22.1-22.7, respectively. These atoms have a strong effect on the electron density of the nearby groups, affecting the chemical shifts. This fact can be also observed either in the methylene group next to $\mathrm{COO}^{-}$, exhibiting chemical shifts at $2.14-2.15 \mathrm{ppm}\left({ }^{1} \mathrm{H}\right)$ or $39.11-39.32\left({ }^{13} \mathrm{C}\right)$, either the ones bonded to cationic nitrogen center, exhibiting resonance at 3.3-3.34 ppm $\left({ }^{1} \mathrm{H}\right)$ and 58.94-58.96 ppm $\left({ }^{13} \mathrm{C}\right)$, respectively. Finally, the carboxylic group of the fatty acid anion showed a chemical shift in the ${ }^{13} \mathrm{C}$ NMR spectra at 179.06-179.3 ppm.

\subsubsection{FTIR}

Fig. 1 shows the vibrational spectra of the two FAILs, both exhibiting important peaks in the 3000-2850 $\mathrm{cm}^{-1}$ zone. This expected behavior was assigned to the stretching vibrations of C-H of methyl units of alkyl chains [59]. In addition, bending vibration of $\mathrm{N}-\mathrm{H}$ bond appeared around $1550 \mathrm{~cm}^{-1}$ [60]. On the other hand, bending vibrations of methyl units in the alkyl chains exhibited peaks close to $1400 \mathrm{~cm}^{-1}$ [59] and the stretching vibration at $1300 \mathrm{~cm}^{-1}$ was assigned to the carboxylic group in the ester [60]. Finally, the signal appearing around $700 \mathrm{~cm}^{-1}$ is probably due to the rocking vibration of an aliphatic chain with four or more carbon atoms [61].

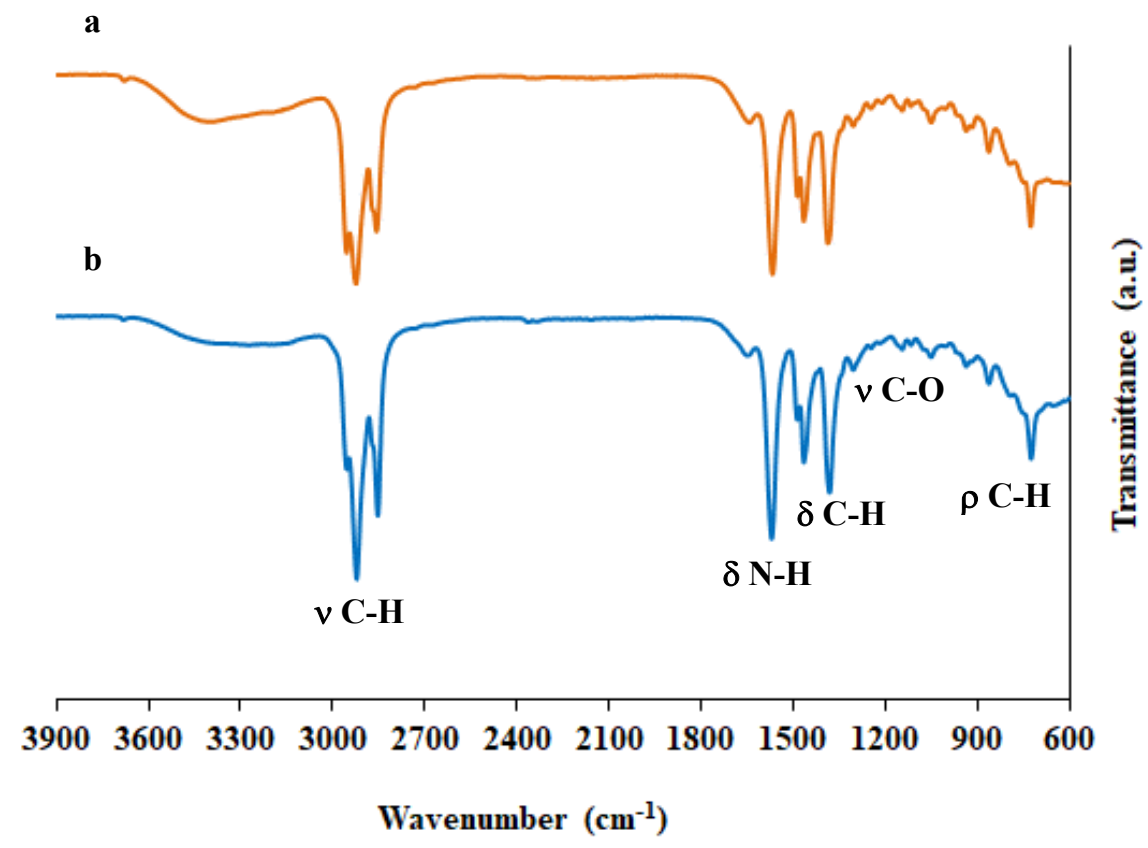

Fig. 1 FTIR spectra of the FAILs including the assignments of the peaks:

a) $\left[\mathrm{N}_{6,6,6,6}\right]\left[\mathrm{C}_{8: 0}\right]$ and b) $\left[\mathrm{N}_{6,6,6,6}\right]\left[\mathrm{C}_{16: 0}\right]$ 


\subsection{Density, viscosity and thermal properties}

Table 2 shows the density and viscosity values of the FAILs studied in this research. For quaternary ammonium ILs, Zhang et al. [62] reported that the higher their number of carbons the lower the density. In addition, Yu et al. [63] observed that longer alkyl chain makes the salt more viscous because of an increase in van der Waals interactions. However, both properties decrease in this research with the increase of the alkyl chain length of the anion, similarly to other FAILs employed in previous research works [64-67]. The differences in viscosity behavior could be explained in a similar way that what happen with surface tension [46]. The alkyl chain interactions seem to have a major contribution to the viscosity while the polar groups of the FAILs seem to have a reduced influence. Therefore, FAILs viscosity behaved like hydrocarbons [68]. In addition, Reeves et al. [69] found that viscosity values of fatty acids converge at high temperatures. This fact is also in agreement with the results found here, both FAILs have close viscosity values at $100{ }^{\circ} \mathrm{C}$. Finally, the $\left[\mathrm{N}_{6,6,6,6}\right]\left[\mathrm{C}_{16: 0}\right]$ IL has the highest viscosity index, showing that an increase in the alkyl chain length improves the lubrication potential of the FAIL $[64,67]$.

Table 2 Density and viscosity values of the ionic liquids.

\begin{tabular}{|c|c|c|c|c|}
\hline \multirow{2}{*}{$\begin{array}{l}\text { Ionic } \\
\text { liquids }\end{array}$} & \multirow{2}{*}{$\begin{array}{c}\text { Density@20ㄷ } \\
\left(\mathrm{g} \cdot \mathrm{cm}^{-3}\right)\end{array}$} & \multicolumn{2}{|c|}{ Kin. viscosity $\left(\mathrm{mm}^{2} \cdot \mathrm{s}^{-1}\right)$} & \multirow{2}{*}{$\begin{array}{l}\text { Viscosity index } \\
\text { ASTM D2270 }\end{array}$} \\
\hline & & $40^{\circ} \mathrm{C}$ & $100^{\circ} \mathrm{C}$ & \\
\hline$\left[\mathrm{N}_{6,6,6,6}\right]\left[\mathrm{C}_{8: 0}\right]$ & 0.9132 & 444.3 & 25.10 & 71 \\
\hline$\left[\mathrm{N}_{6,6,6,6}\right]\left[\mathrm{C}_{16: 0}\right]$ & 0.8848 & 243.0 & 19.80 & 93 \\
\hline
\end{tabular}

Fig. 2 displays the thermogravimetric analysis (TGA) of the two FAILs used in this research. It is important to notice that both samples are completely degraded around half the maximum temperature used in this test $\left(600^{\circ} \mathrm{C}\right)$. Besides, the onset of temperature degradation was between 165 and $180{ }^{\circ} \mathrm{C}$ (Table 3 ).

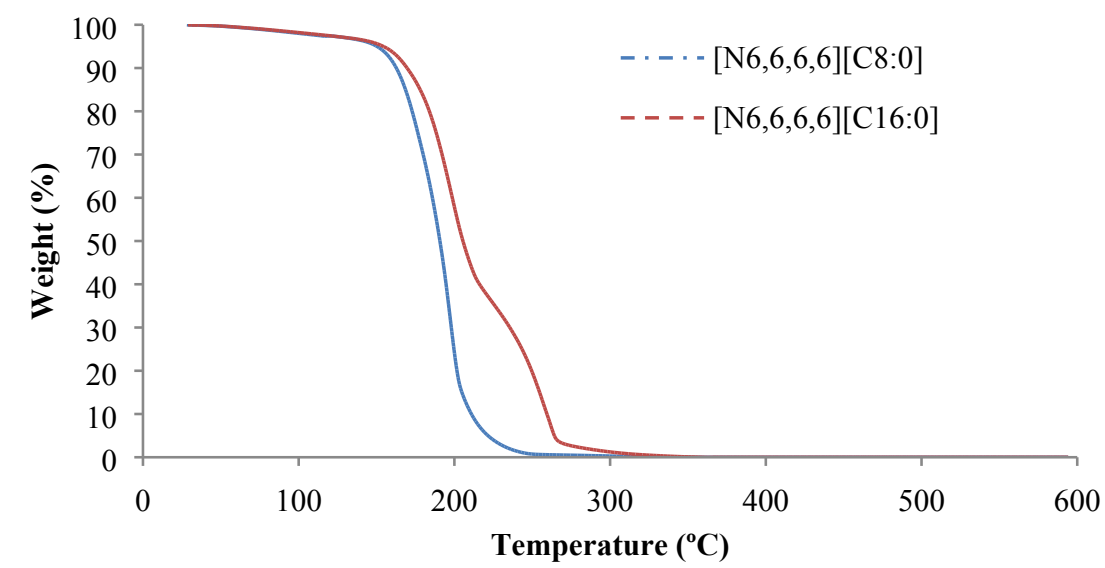

Fig. 2 Thermogravimetric behavior of the ionic liquids. 
Comparing these mentioned results with that of two ILs containing the same anions obtained in a previous research, it was found that thermogravimetric results are almost the same until $\mathrm{T}_{50 \%}$ (around $200{ }^{\circ} \mathrm{C}$ ) [64]. However, the FAILs studied in this work exhibited a drastic loss of mass from this moment, especially the $\left[\mathrm{N}_{6,6,6,6}\right]\left[\mathrm{C}_{8: 0}\right]$, reaching the $\mathrm{T}_{100 \%}$ in the zone between $330-360{ }^{\circ} \mathrm{C}$.

Table 3 Thermal properties of the ionic liquids.

\begin{tabular}{cccccc}
\hline ILs & $\mathrm{T}_{\text {onset }}\left({ }^{\circ} \mathrm{C}\right)$ & $\mathrm{T}_{10 \%}\left({ }^{\circ} \mathrm{C}\right)$ & $\mathrm{T}_{20 \%}\left({ }^{\circ} \mathrm{C}\right)$ & $\mathrm{T}_{50 \%}\left({ }^{\circ} \mathrm{C}\right)$ & $\mathrm{T}_{100 \%}\left({ }^{\circ} \mathrm{C}\right)$ \\
\hline$\left[\mathrm{N}_{6,6,6,6}\right]\left[\mathrm{C}_{8: 0}\right]$ & 167.1 & 162.3 & 172.9 & 190.8 & 331.2 \\
{$\left[\mathrm{~N}_{6,6,6,6}\right]\left[\mathrm{C}_{16: 0}\right]$} & 176.1 & 169.6 & 184.0 & 205.5 & 359.5 \\
\hline
\end{tabular}

\subsection{Corrosion tests}

No signs of corrosion attack appeared in any of the experiments carried out. The steel surfaces tested with the FAILs did not show physical changes in comparison to a non-treated steel surface. In addition, the steel surface analyzed by scanning electron microscopy (SEM) and energy-dispersive spectroscopy (EDS) confirmed the absence of corrosion, showing only the presence of the elements of the steel surface (Table 4) and a higher carbon content with the one reported for the AISI 52100 steel (Table 1). That result could be a consequence of possible remaining ionic liquid or cleaning solvent from those employed in the test.

Table 4 EDS analysis (at. concentration, \%) on the disc surface after corrosion tests.

\begin{tabular}{lcccc}
\hline \multicolumn{1}{c}{ FAILs / Time and Temperature } & $\mathbf{C}$ & $\mathbf{C r}$ & $\mathbf{M n}$ & $\mathbf{F e}$ \\
\hline None (non-treated disc) & 8.35 & 1.62 & 0.53 & 89.50 \\
{$\left[\mathrm{~N}_{6,6,6,6}\right]\left[\mathrm{C}_{8: 0}\right] / 2$ weeks at RT } & 11.31 & 1.71 & 0.02 & 86.96 \\
{$\left[\mathrm{~N}_{6,6,6,6}\right]\left[\mathrm{C}_{16: 0}\right] 2$ weeks at RT } & 12.74 & 1.47 & 0.17 & 85.63 \\
{$\left[\mathrm{~N}_{6,6,6,6}\right]\left[\mathrm{C}_{8: 0}\right] 1$ year at RT } & 9.06 & 1.55 & 0.16 & 89.23 \\
{$\left[\mathrm{~N}_{6,6,6,6}\right]\left[\mathrm{C}_{16: 0}\right] 1$ year at RT } & 8.35 & 1.62 & 0.53 & 89.50 \\
{$\left[\mathrm{~N}_{6,6,6,6}\right]\left[\mathrm{C}_{8: 0}\right] 24 \mathrm{~h}$ at $100{ }^{\circ} \mathrm{C}$} & 16.15 & 1.57 & 0.63 & 81.65 \\
{$\left[\mathrm{~N}_{6,6,6,6}\right]\left[\mathrm{C}_{16: 0}\right] 24 \mathrm{~h}$ at $100^{\circ} \mathrm{C}$} & 5.67 & 1.53 & 0.28 & 92.51 \\
\hline
\end{tabular}

\subsection{Tribological properties of the FAILs}

The Stribeck curve of both FAILs were obtained at different temperatures $\left(40,60,80,100^{\circ} \mathrm{C}\right)$. Fig. 3 shows that both FAILs operate under elastohydrodynamic lubrication at all speeds at $40{ }^{\circ} \mathrm{C}$, with $\left[\mathrm{N}_{6,6,6,6}\right]\left[\mathrm{C}_{16: 0}\right]$ 
operating under above mentioned lubrication regime even at $60^{\circ} \mathrm{C}$ at almost all speeds (a slight increase in the friction coefficient occurs at speed around $20 \mathrm{~mm} / \mathrm{s}$ ).
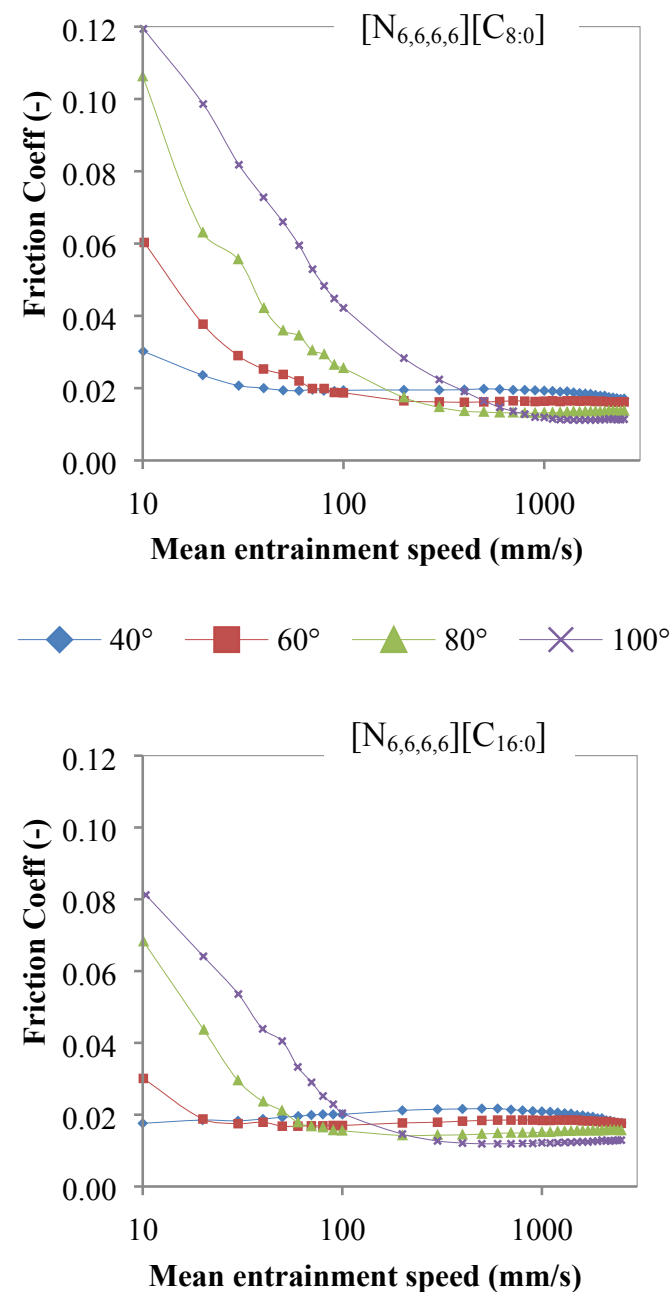

$\neg 40^{\circ}-60^{\circ} \triangle 80^{\circ} \longrightarrow 100^{\circ}$
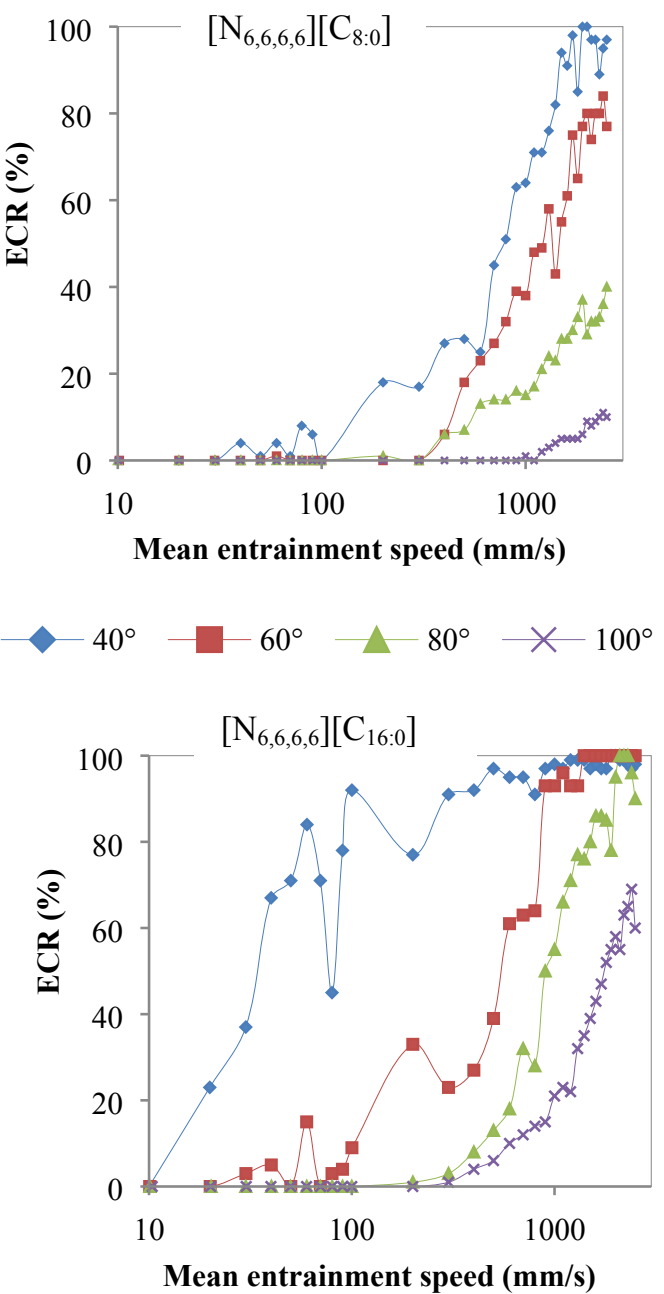

$\longrightarrow 40^{\circ}-60^{\circ} \longrightarrow 80^{\circ} \times 100^{\circ}$

Fig. 3 Friction coefficient (Stribeck curves) and electrical contact resistance (ECR) during tests at different temperatures.

Besides, a slight increase of friction coefficient with speed was verified under these low temperature conditions, especially in the case of $\left[\mathrm{N}_{6,6,6,6}\right]\left[\mathrm{C}_{16: 0}\right]$. This performance could be caused by the high viscosity values for the FAILs at this temperature, provoking a growth in the lubricant film thickness that avoids metal-metal contact. However, this behavior is less clear than the obtained with other FAILs with higher viscosity values [64]. On the other hand, the thinner lubricant film obtained at low speeds $(<100 \mathrm{~mm} / \mathrm{s})$ provokes metal-metal contact and the corresponding increase in friction coefficient and decrease in the ECR. This behavior is much less pronounced in the case of $\left[\mathrm{N}_{6,6,6,6}\right]\left[\mathrm{C}_{16: 0}\right]$. The $\left[\mathrm{N}_{6,6,6,6}\right]\left[\mathrm{C}_{8: 0}\right]$ changed from elastohydrodynamic to mixed lubrication regime at higher speeds and temperatures than the $\left[\mathrm{N}_{6,6,6,6}\right]\left[\mathrm{C}_{16: 0}\right]$ 
due to its lower viscosity index, which lead to a quick reduction of viscosity with temperature and hence a lubricant film thickness reduction and an increase of friction coefficient.

Fig. 4 exhibits the results from traction tests performed at variable SRR values and at different temperatures. Both FAILs had similar behavior: the friction coefficient increased when the SRR varied from 5 to $50 \%$, being $\left[\mathrm{N}_{6,6,6,6}\right]\left[\mathrm{C}_{8: 0}\right]$ slightly better from a friction point of view at all temperatures. The friction coefficient decreased with temperature because for the speed used $\left(2000 \mathrm{~mm} \cdot \mathrm{s}^{-1}\right)$ the test was performed under elastohydrodynamic lubrication regime (see in Fig. 3 that tests performed at $2000 \mathrm{~mm} \cdot \mathrm{s}^{-1}$ and SRR of $50 \%$ took place under elastohydrodynamic lubrication regime). In addition, the friction coefficient decreases at SRR values lower than $50 \%$ because the sliding component in the contact is lower.
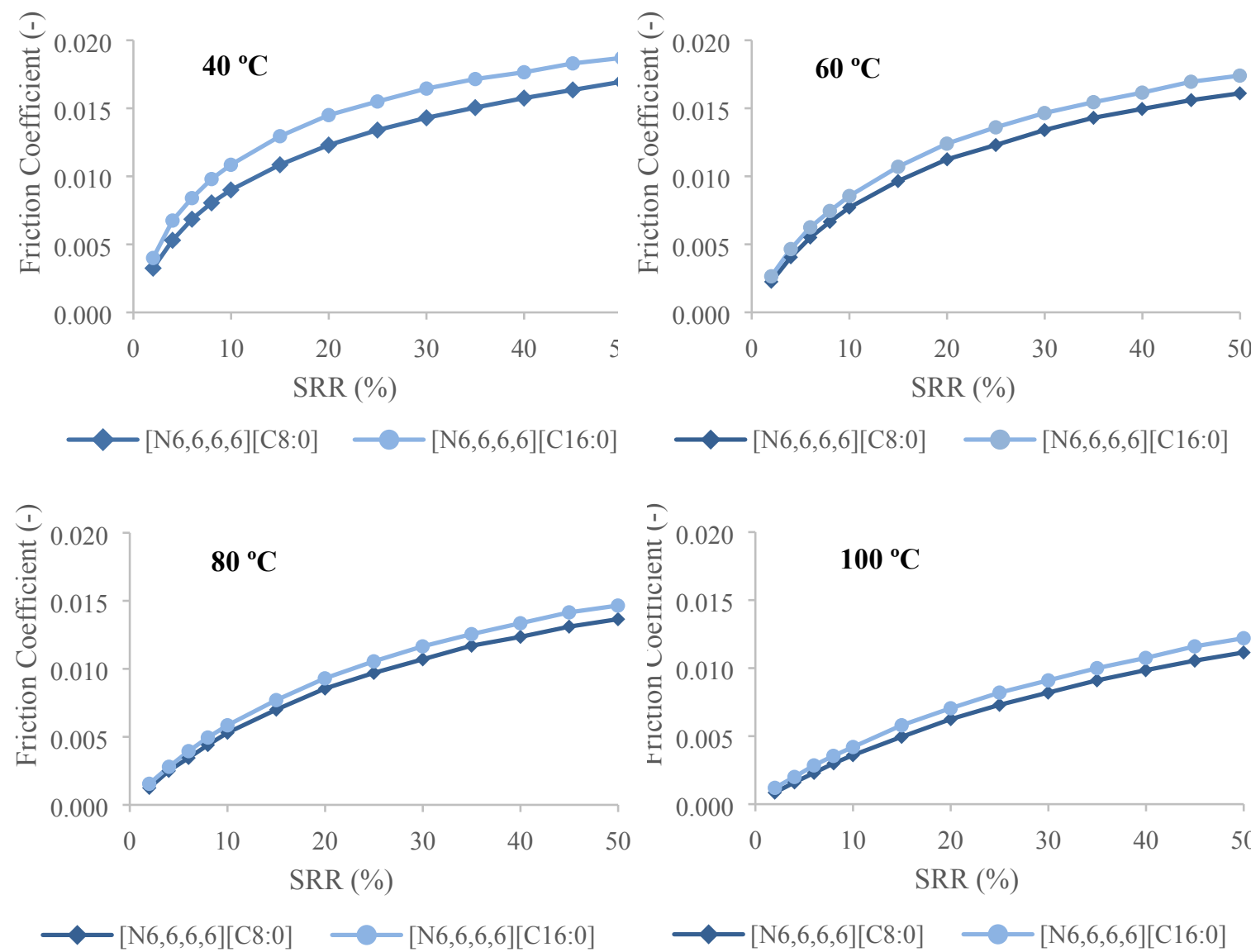

Fig. 4 Friction behaviour of the $\left[\mathrm{N}_{6,6,6,6}\right]\left[\mathrm{C}_{8: 0}\right]$ and $\left[\mathrm{N}_{6,6,6,6}\right]\left[\mathrm{C}_{16: 0}\right]$ at different temperatures and variable SRR values.

The tribological tests made under a reciprocating ball-on-disc configuration showed that in general the $\left[\mathrm{N}_{6,6,6,6}\right]\left[\mathrm{C}_{8: 0}\right]$ reduces friction more effectively than the $\left[\mathrm{N}_{6,6,6,6}\right]\left[\mathrm{C}_{16: 0}\right]$, Fig. 5. The $\left[\mathrm{N}_{6,6,6,6}\right]\left[\mathrm{C}_{16: 0}\right]$ only performed better at $25{ }^{\circ} \mathrm{C}$ and $10 \mathrm{~N}$, probably due to its lower viscosity combined with softer contact conditions, which lead to a thicker lubricant film thickness where friction is controlled by the lubricant 
viscosity. At both higher loads and temperature, the higher friction coefficient values registered with the use of the $\left[\mathrm{N}_{6,6,6,6}\right]\left[\mathrm{C}_{16: 0}\right]$ can be related to its lower viscosity, which promotes thinner lubricant film thickness and more asperities contact.
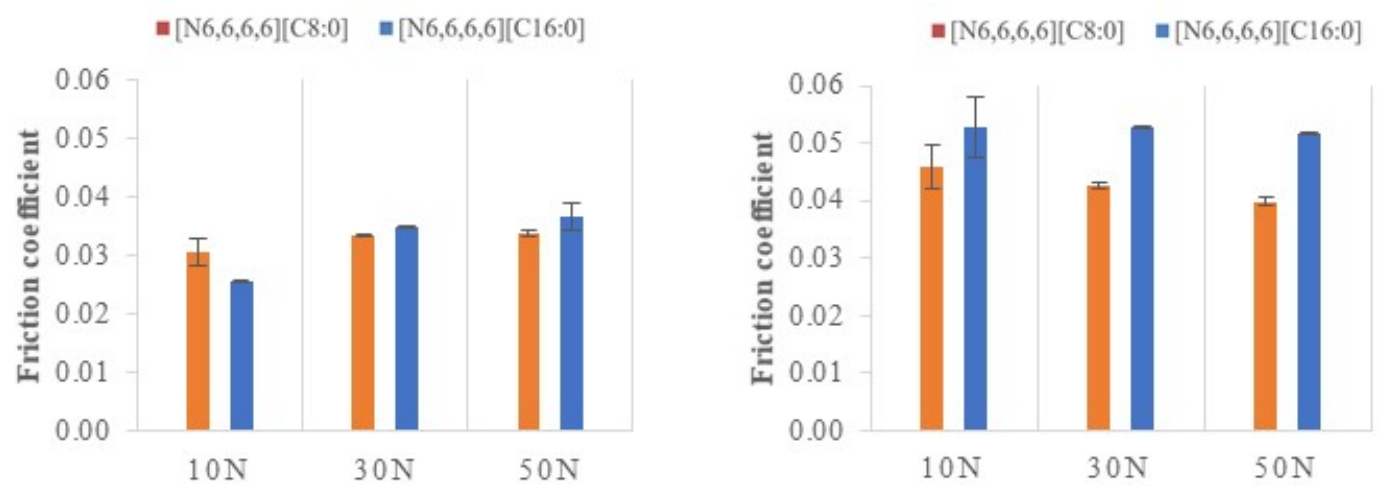

Fig. 5 Friction coefficient in the 30 -min tribological tests at: left: $25^{\circ} \mathrm{C}$; right: $100{ }^{\circ} \mathrm{C}$.

Fig. 6 shows the wear volume measured on the disc surface after 30-min tribological tests. As expected wear increased with temperature. The use of $\left[\mathrm{N}_{6,6,6,6}\right]\left[\mathrm{C}_{8: 0}\right]$ and $\left[\mathrm{N}_{6,6,6,6}\right]\left[\mathrm{C}_{16: 0}\right]$ led to similar wear volume values under both 10 and $30 \mathrm{~N}$-load for each temperature (Fig. 7). However, the antiwear behavior of the FAILs changed with temperature at $50 \mathrm{~N}$-load. This performance at room temperature could be attributed to the quite higher viscosity of the $\left[\mathrm{N}_{6,6,6,6}\right]\left[\mathrm{C}_{8: 0}\right]$ with regard to that of the $\left[\mathrm{N}_{6,6,6,6}\right]\left[\mathrm{C}_{16: 0}\right]$, whereas at high temperature $\left(100^{\circ} \mathrm{C}\right)$ the better thermal stability of the $\left[\mathrm{N}_{6,6,6,6}\right]\left[\mathrm{C}_{16: 0}\right]$ favoured lubrication.
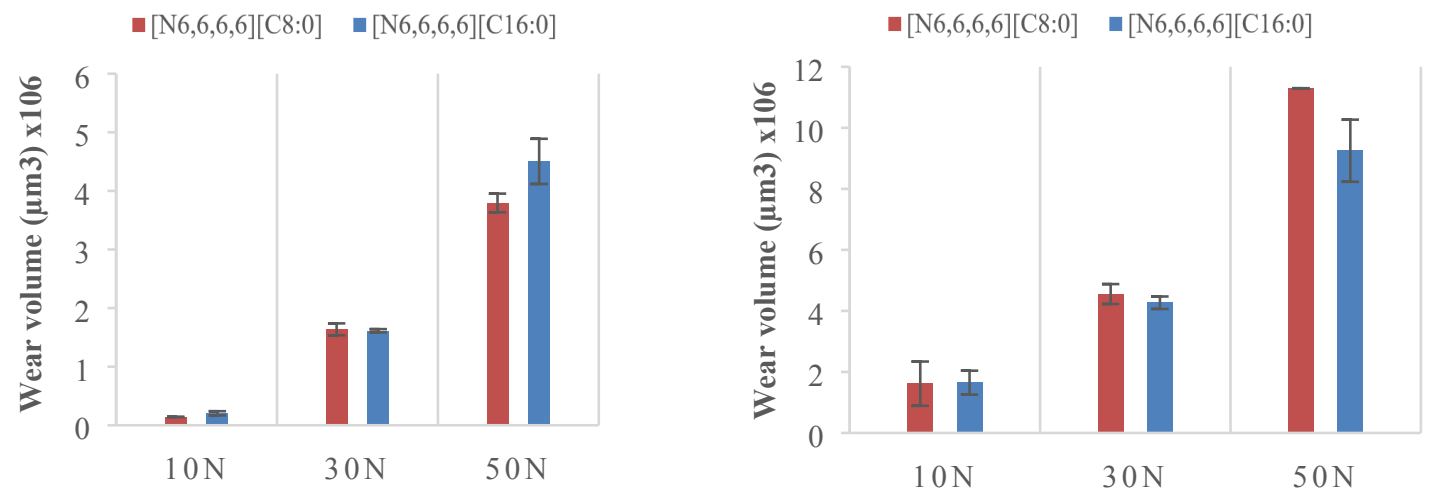

Fig. 6 Wear volume after the 30 -min tribological tests at: a) $25^{\circ} \mathrm{C}$; b) $100{ }^{\circ} \mathrm{C}$.

The wear scar images obtained by SEM after the 30 -min tribological tests at $25{ }^{\circ} \mathrm{C}$ are shown in Fig. 7. The increase of load results in a higher width of the wear track as expected and the wear mechanism found in all samples seemed to be plastic deformation due to an adhesive process. No relevant wear differences between the two FAILs can be found under the same testing conditions, except at $50 \mathrm{~N}$-load as it was explained in the discussion of Fig. 6 . 

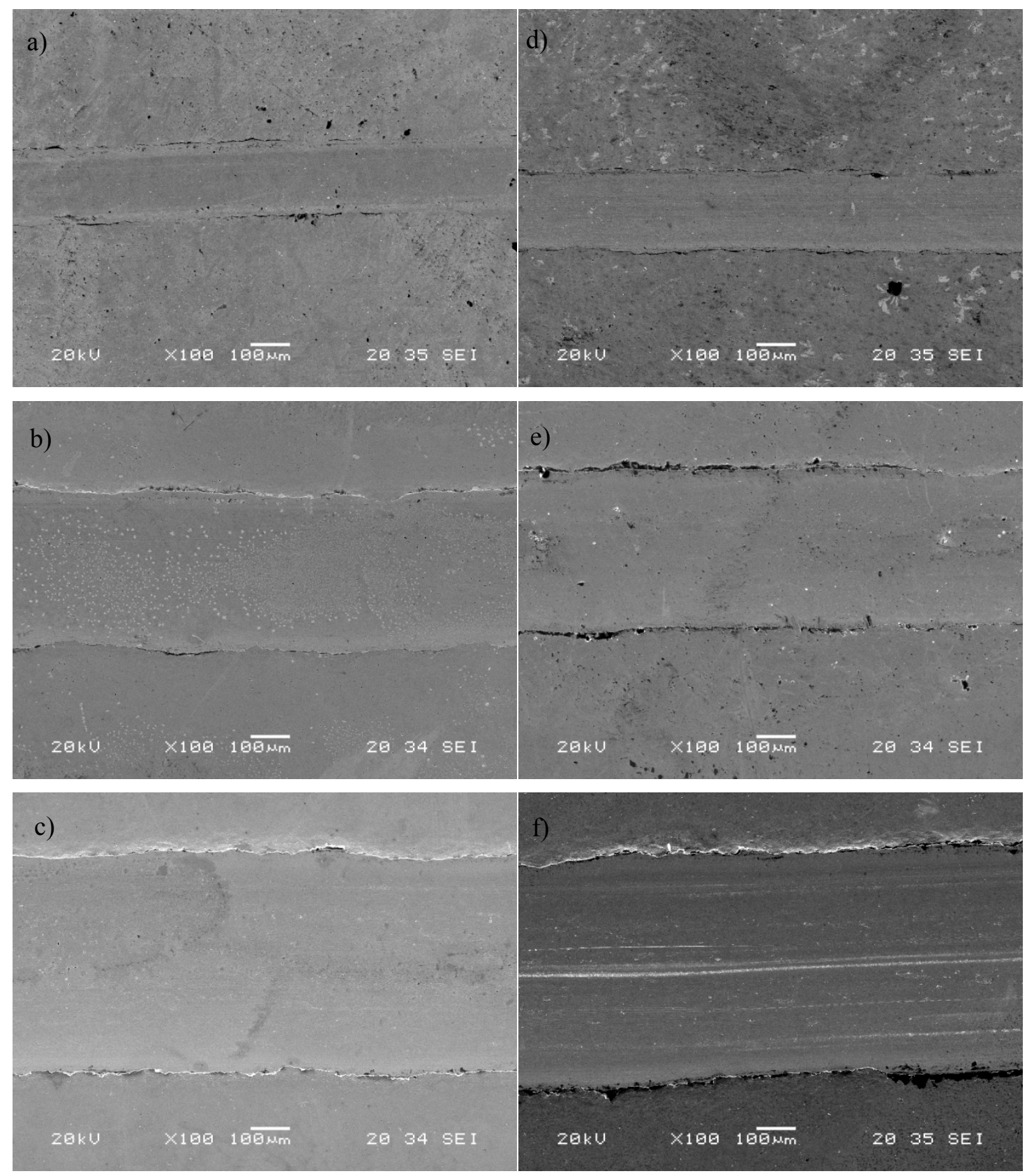

Fig. 7 Worn surfaces after tribological tests at $25^{\circ} \mathrm{C}$ : (a) $\left[\mathrm{N}_{6,6,6,6}\right]\left[\mathrm{C}_{8: 0}\right]$ at $10 \mathrm{~N}$; (b) $\left[\mathrm{N}_{6,6,6,6}\right]\left[\mathrm{C}_{8: 0}\right]$ at $30 \mathrm{~N}$; (c) $\left[\mathrm{N}_{6,6,6,6}\right]\left[\mathrm{C}_{8: 0}\right]$ at $50 \mathrm{~N}$; (d) $\left[\mathrm{N}_{6,6,6,6}\right]\left[\mathrm{C}_{16: 0}\right]$ at $10 \mathrm{~N}$; (e) $\left[\mathrm{N}_{6,6,6,6}\right]\left[\mathrm{C}_{16: 0}\right]$ at $30 \mathrm{~N}$; (f) $\left[\mathrm{N}_{6,6,6,6}\right]\left[\mathrm{C}_{16: 0}\right]$ at $50 \mathrm{~N}$.

In addition, Fig. 8 shows the corresponding wear scar images of tests made at $100^{\circ} \mathrm{C}$. The wear scar width rises with load as in tests at $25^{\circ} \mathrm{C}$ and the wear mechanism in this case was the same. However, the impact of higher temperature is quite visible on the wear surface resulting in a higher degree of plastic deformation and more material displacement to the edge of the wear scar. 

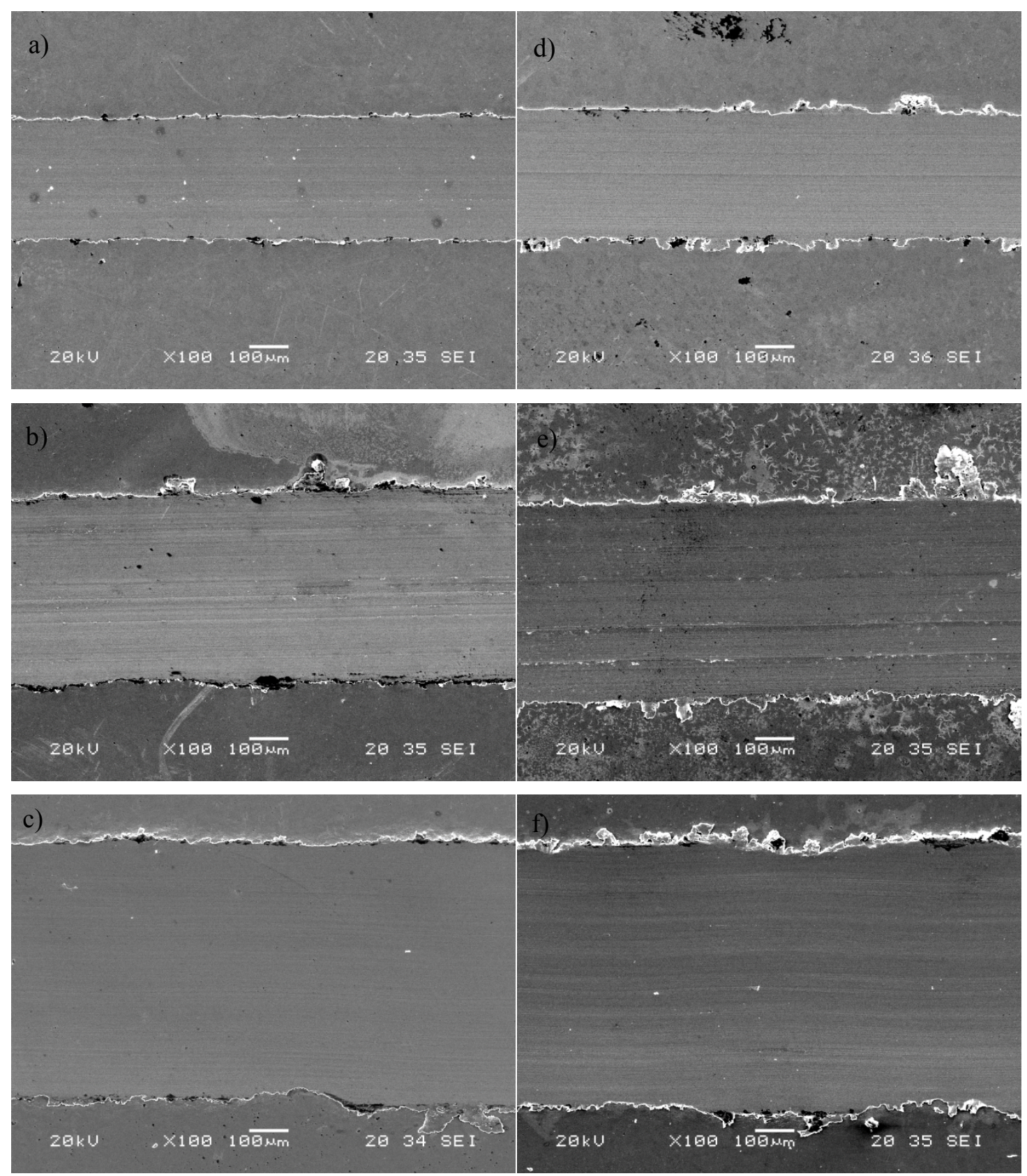

Fig. 8 Worn surfaces after tribological tests at $100{ }^{\circ} \mathrm{C}$ : (a) $\left[\mathrm{N}_{6,6,6,6}\right]\left[\mathrm{C}_{8: 0}\right]$ at $10 \mathrm{~N}$; (b) $\left[\mathrm{N}_{6,6,6,6}\right]\left[\mathrm{C}_{8: 0}\right]$ at $30 \mathrm{~N}$; (c) $\left[\mathrm{N}_{6,6,6,6}\right]\left[\mathrm{C}_{8: 0}\right]$ at $50 \mathrm{~N}$; (d) $\left[\mathrm{N}_{6,6,6,6}\right]\left[\mathrm{C}_{16: 0}\right]$ at $10 \mathrm{~N}$; (e) $\left[\mathrm{N}_{6,6,6,6}\right]\left[\mathrm{C}_{16: 0}\right]$ at $30 \mathrm{~N}$; (f) $\left[\mathrm{N}_{6,6,6,6}\right]\left[\mathrm{C}_{16: 0}\right]$ at $50 \mathrm{~N}$.

The EDS analysis from all wear scars (Table 5) showed that the presence of oxygen increases at higher temperature $\left(100^{\circ} \mathrm{C}\right)$, suggesting an interaction between the FAIL and the surface. On the other hand, the presence of organic matter (carbon and oxygen) seems to be a little bit higher under $\left[\mathrm{N}_{6,6,6,6}\right]\left[\mathrm{C}_{16: 0}\right]$ lubrication, which could also explain their better wear behaviour. In all cases, the EDS analysis showed that mainly the elements present in the steel disc were found on the wear scar (with the addition of oxygen at $\left.100^{\circ} \mathrm{C}\right)$. 
Table 5. EDS analysis (at. concentration, \%) after 30-min tribological tests.

\begin{tabular}{lccccc}
\hline FAILs / Load / Temperature & $\mathbf{C}$ & $\mathbf{O}$ & $\mathbf{C r}$ & $\mathbf{F e}$ & $\mathbf{Z n}$ \\
\hline$\left[\mathrm{N}_{6,6,6,6}\right]\left[\mathrm{C}_{8: 0}\right]-10 \mathrm{~N}-25^{\circ} \mathrm{C}$ & 1.83 & 0.01 & 1.59 & 96.12 & 0.45 \\
{$\left[\mathrm{~N}_{6,6,6,6}\right]\left[\mathrm{C}_{8: 0}\right]-30 \mathrm{~N}-25^{\circ} \mathrm{C}$} & 2.49 & 0 & 1.90 & 95.12 & 0.49 \\
{$\left[\mathrm{~N}_{6,6,6,6}\right]\left[\mathrm{C}_{8: 0}\right]-50 \mathrm{~N}-25^{\circ} \mathrm{C}$} & 3.01 & 0.27 & 1.76 & 94.93 & 0.03 \\
\hline$\left[\mathrm{N}_{6,6,6,6}\right]\left[\mathrm{C}_{8: 0}\right]-10 \mathrm{~N}-100^{\circ} \mathrm{C}$ & 4.48 & 4.51 & 3.74 & 87.24 & 0.03 \\
{$\left[\mathrm{~N}_{6,6,6,6}\right]\left[\mathrm{C}_{8: 0}\right]-30 \mathrm{~N}-100^{\circ} \mathrm{C}$} & 3.95 & 6.84 & 4.20 & 84.79 & 0.22 \\
{$\left[\mathrm{~N}_{6,6,6,6}\right]\left[\mathrm{C}_{8: 0}\right]-50 \mathrm{~N}-100^{\circ} \mathrm{C}$} & 6.29 & 6.14 & 3.63 & 83.54 & 0.40 \\
\hline$\left[\mathrm{N}_{6,6,6,6}\right]\left[\mathrm{C}_{16: 0}\right]-10 \mathrm{~N}-25^{\circ} \mathrm{C}$ & 2.00 & 0.48 & 1.54 & 95.88 & 0.10 \\
{$\left[\mathrm{~N}_{6,6,6,6,6}\right]\left[\mathrm{C}_{16: 0}\right]-30 \mathrm{~N}-25^{\circ} \mathrm{C}$} & 4.25 & 0.28 & 1.75 & 93.30 & 0.42 \\
{$\left[\mathrm{~N}_{6,6,6,6}\right]\left[\mathrm{C}_{16: 0}\right]-50 \mathrm{~N}-25^{\circ} \mathrm{C}$} & 2.44 & 0 & 1.77 & 95.89 & 0.15 \\
\hline$\left[\mathrm{N}_{6,6,6,6}\right]\left[\mathrm{C}_{16: 0}\right]-10 \mathrm{~N}-100^{\circ} \mathrm{C}$ & 3.73 & 7.18 & 2.70 & 86.32 & 0.07 \\
{$\left[\mathrm{~N}_{6,6,6,6}\right]\left[\mathrm{C}_{16: 0}\right]-30 \mathrm{~N}-100^{\circ} \mathrm{C}$} & 5.60 & 5.54 & 2.43 & 86.06 & 0.37 \\
{$\left[\mathrm{~N}_{6,6,6,6}\right]\left[\mathrm{C}_{16: 0}\right]-50 \mathrm{~N}-100^{\circ} \mathrm{C}$} & 4.10 & 7.5 & 4.29 & 83.66 & 0.45 \\
\hline
\end{tabular}

\section{Conclusions}

A couple of novel fatty acid anion-based ionic liquids (FAILs): tetrahexylammonium octanoate $\left(\left[\mathrm{N}_{6,6,6,6}\right]\left[\mathrm{C}_{8: 0}\right]\right)$ and tetrahexylammonium hexadecanoate $\left(\left[\mathrm{N}_{6,6,6,6}\right]\left[\mathrm{C}_{16: 0}\right]\right)$ were synthesized and identified by NMR and FTIR techniques. Physicochemical properties of these two ionic liquids, such as density, viscosity, corrosion activity and thermal stability, were tested before studying their tribological properties in steel-steel contacts when they are used as neat lubricants. From the results obtained can be drawn the following conclusions:

- Viscosity and density values are higher in the case of the $\left[\mathrm{N}_{6,6,6,6}\right]\left[\mathrm{C}_{8: 0}\right]$, which can be attributed to its shorter alkyl chain length in the anion. On the other hand, the $\left[\mathrm{N}_{6,6,6,6}\right]\left[\mathrm{C}_{16: 0}\right]$ showed a higher viscosity index.

- The $\left[\mathrm{N}_{6,6,6,6}\right]\left[\mathrm{C}_{16: 0}\right]$ showed better thermal stability than the $\left[\mathrm{N}_{6,6,6,6}\right]\left[\mathrm{C}_{8: 0}\right]$. The thermal stability of these FAILs are lower than that of the traditional ionic liquids studied before in lubrication studies.

- None of these ionic liquids presented corrosive activity on the steel surfaces.

- Both FAILs performed under elastohydrodynamic lubrication regime at the lowest temperature $\left(40{ }^{\circ} \mathrm{C}\right)$ for all speed range tested and changed to mixed lubrication regimen at increasing temperatures but the $\left[\mathrm{N}_{6,6,6,6}\right]\left[\mathrm{C}_{16: 0}\right]$ behaved better changing to a mixed lubrication regime at lower speeds. 
- Both FAILs had similar antiwear behavior at 10 and $30 \mathrm{~N}$-load for each temperature but at the highest load showed different behavior probably due to their quite different viscosity at room temperature and the higher thermal stability of the $\left[\mathrm{N}_{6,6,6,6}\right]\left[\mathrm{C}_{16: 0}\right]$ at high temperature.

- The EDS detected higher presence of organic matter (carbon and oxygen) on the wear scar under the $\left[\mathrm{N}_{6,6,6,6}\right]\left[\mathrm{C}_{16: 0}\right]$ lubrication, which suggest an interaction between the FAIL and the surface, especially at $100{ }^{\circ} \mathrm{C}$.

\section{Acknowledgements}

The authors thank the Spanish Ministry of Economy and Competitiveness and the Foundation for the Promotion of Applied Scientific Research and Technology in Asturias (FICYT) for supporting this work under the framework of the research projects FAILs_LUBEs (DPI2016-79690-R) and LuSuTec (IDI/2018/000131), respectively.

\section{References}

[1] H.P. Jost, Lubrication (tribology) - A Report on the Present Position and Industry's Needs, Department of Education and Science, H.M. Stationery Office, London, 1966. https://www.worldcat.org/title/lubrication-tribology-education-and-research-a-report-on-the-presentposition-and-industrys-needs/oclc/3751788 (accessed 18 December 2019).

[2] Institution of Mechanical Engineers (Great Britain), Tribology Group, First European Tribology Congress, London, 1973, in: Mechanical Engineering Publications for the Institution of Mechanical Engineers, London and New York, 1975. https://doi.org/catalogue.nla.gov.au/Record/2637832.

[3] K. Holmberg, A. Erdemir, Influence of tribology on global energy consumption, costs and emissions. Friction 5(3) (2017) 263-284. https://doi.org/10.1007/s40544-017-0183-5.

[4] J.K. Mannekote, P.L. Menezes, S.V. Kailas, R.K.C. Sathwik, Tribology of green lubricants, in: Tribol. Sci. Eng., Springer, New York, 2013: pp. 495-521. https://doi.org/10.1007/978-1-4614-1945-7_14.

[5] C.J. Reeves, P.L. Menezes, Advances in eco-friendly lubricants for tribological applications: past, present, and future, in: J.P. Davim (Eds.), Ecotribology, Materials Forming, Machining and Tribology, Springer, New York, 2016. https://doi.org/10.1007/978-3-319-24007-7. 
[6] C. Ye, W. Liu, Y. Chen, L. Yu, Room-temperature ionic liquids: a novel versatile lubricant, Chem. Commun. (2001) 2244-2245. https://doi.org/10.1039/b106935g.

[7] F. Guo, S. Zhang, J. Wang, B. Teng, T. Zhang, M. Fan, Synthesis and applications of ionic liquids in clean energy and environment: a review, Curr. Org. Chem. 19(5) (2015) 455-468. https://doi.org/10.2174/1385272819666150114235649.

[8] A. Berthod, M.J. Ruiz-Ángel, S. Carda-Broch, Recent advances on ionic liquid uses in separation techniques, J. Chromatogr. A 1559 (2018) 2-16. https://doi:10.1016/j.chroma.2017.09.044.

[9] H. Liu, H. Yu, Ionic liquids for electrochemical energy storage devices applications, J. Mater. Sci. Technol. 35 (2019) 674-686. https://doi:10.1016/j.jmst.2018.10.007.

[10] Z. Ullah, A.S. Khan, N. Muhammad, R. Ullah, A.S. Alqahtani, S.N. Shah, O.B. Ghanem, M.A. Bustam, Z. Man, A review on ionic liquids as perspective catalysts in transesterification of different feedstock oil into biodiesel, J. Mol. Liq. $266 \quad$ (2018) 673-686. https://doi:10.1016/j.molliq.2018.06.024.

[11] L. Zhang, B. Zhao, Y. Zhang, Q. Zhao, H. Chu, Z. Liang, Advances of ionic liquids-based methods for protein analysis. TrAC Trends Anal. Chem. $108 \quad$ (2018) 239-246. https://doi:10.1016/j.trac.2018.09.008.

[12] F. Javed, F. Ullah, M.R. Zakaria, H.M. Akil, An approach to classification and hi-tech applications of room-temperature ionic liquids (RTILs): a review, J. Mol. Liq. 271 (2018) 403-420. https://doi:10.1016/j.molliq.2018.09.005.

[13] M. Aghaie, N. Rezaei, S. Zendehboudi, A systematic review on CO2 capture with ionic liquids: current status and future prospects. Renew. Sustain. Energy Rev. 96 (2018) 502-525. https://doi:10.1016/j.rser.2018.07.004.

[14] L.Y. Wang, Q.J. Guo, M.S. Lee, Recent advances in metal extraction improvement: mixture systems consisting of ionic liquid and molecular extractant, Sep. Purif. Technol. 210 (2019) 292-303. https://doi:10.1016/j.seppur.2018.08.016.

[15] M.D. Bermúdez, A.E. Jiménez, J. Sanes, F.J. Carrión, Ionic liquids as advanced lubricant fluids, Molecules 14 (2009) 2888-2908. https://doi.org/10.3390/molecules14082888.

[16] I. Minami. Ionic liquids in tribology, Molecules 14(6) (2009) 2286-2305. https://doi.org/10.3390/molecules14062286. 
[17] F. Zhou, Y. Liangm, W. Liu, Ionic liquid lubricants: designed chemistry for engineering applications, Chemical Society Reviews, 38(9) (2009) 2590-2599. https://doi.org/10.1039/b817899m.

[18] K.J. Fraser, D.R. MacFarlane, Phosphonium-based ionic liquids: an overview, Australian Journal of Chemistry, 62(4) (2009) 309-321. https://doi.org/10.1071/CH08558.

[19] M. Palacio, B. Bhushan, A review of ionic liquids for green molecular lubrication in nanotechnology, Tribology Letters, 40(2) (2010) 247-268. https://doi.org/10.1007/s11249-010-9671-8.

[20] J. Van Rensselar, (2010). Unleashing the potential of ionic liquids, Tribology \& Lubrication Technology 66(4) (2010) 24-31.

[21] A.E. Somers, P.C. Howlett, D.R. MacFarlane, M. Forsyth, (2013), A review of ionic liquid lubricants. Lubricants, 1(1) (2013) 3-21. https://doi.org/10.3390/lubricants1010003.

[22] H. Xiao, Ionic liquid lubricants: basics and applications, Tribology Transactions 60(1) (2017) 20-30. https://doi.org/10.1080/10402004.2016.1142629.

[23] Y. Zhou, J. Qu, Ionic liquids as lubricant additives - a review. ACS Applied Materials and Interfaces, 9(4) (2016) 3209-3222. https://doi.org/10.1021/acsami.6b12489.

[24] S.A.S. Amiril, E.A. Rahim, S. Syahrullail, A review on ionic liquids as sustainable lubricants in manufacturing and engineering: recent research, performance, and applications. J. Clean Prod. 168 (2017) 1571-1589. https://doi:10.1016/j.jclepro.2017.03.197.

[25] A. Hernández Battez, M. Bartolomé, D. Blanco, J.L. Viesca, A. Fernández-González, R. González, Phosphonium cation-based ionic liquids as neat lubricants: Physicochemical and tribological performance. Tribol. Int. 95 (2016) 118-131. https://doi.org/10.1016/j.triboint.2015.11.015.

[26] H. Kamimura, T. Kubo, I. Minami, S. Mori, Effect and mechanism of additives for ionic liquids as new lubricants, Tribol. Int. 40 (2007) 620-625. https://doi.org/10.1016/j.triboint.2005.11.009.

[27] V. Sharma, C. Gabler, N. Doerr, P.B. Aswath, Mechanism of tribofilm formation with P and S $\begin{array}{llllll}\text { containing ionic } & \text { liquids. } & \text { Tribol. } & \text { Int., } & 92 & \text { (2015) }\end{array}$ https://doi.org/10.1016/j.triboint.2015.07.009.

[28] A.H. Battez, C.M.C.G. Fernandes, R.C. Martins, M. Bartolomé, R. González, J.H.O. Seabra, Two phosphonium cation-based ionic liquids used as lubricant additive. Part I: film thickness and friction characteristics. Tribol. Int., 107 (2017) 233-239. https://doi.org/10.1016/j.triboint.2016.10.048.

[29] A.H. Battez, C.M.C.G. Fernandes, R.C. Martins, B.M. Graça, M. Anand, D. Blanco, J.H.O. Seabra, Two phosphonium cation-based ionic liquids used as lubricant additive. Part II: tribofilm analysis and 
friction torque loss in cylindrical roller thrust bearings at constant temperature. Tribol. Int., 109 (2017) 496-504. https://doi.org/10.1016/j.triboint.2017.01.020.

[30] S.P.M. Ventura, C.S. Marques, A.A. Rosatella, C.A.M. Afonso, F. Gonçalves, J.A.P. Coutinho, Toxicity assessment of various ionic liquid families towards Vibrio fischeri marine bacteria. Ecotoxicol. Environ. Saf. 76 (2012) 162-168. https://doi:10.1016/j.ecoenv.2011.10.006.

[31] D. Zhao, Y. Liao, Z.D. Zhang, Toxicity of ionic liquids. Clean - Soil, Air, Water 35 (2007) 42-48. https://doi:10.1002/clen.200600015.

[32] J. Salgado, J.J. Parajó, T. Teijeira, O. Cruz, J. Proupín, M. Villanueva, J.A. Rodríguez-Añón, P.V. Verdes, O. Reyes, New insight into the environmental impact of two imidazolium ionic liquids. Effects on seed germination and soil microbial activity, Chemosphere 185 (2017) 665-672. https://doi:10.1016/j.chemosphere.2017.07.065.

[33] J. Neumann, S. Steudte, C.W. Cho, J. Thöming, S. Stolte, Biodegradability of 27 pyrrolidinium, morpholinium, piperidinium, imidazolium and pyridinium ionic liquid cations under aerobic conditions, Green Chem. 16 (2014) 2174-2184. https://doi:10.1039/C3GC41997E.

[34] S. Ma, M. Lv, F. Deng, X. Zhang, H. Zhai, W. Lv, Predicting the ecotoxicity of ionic liquids towards Vibrio fischeri using genetic function approximation and least squares support vector machine. J Hazard Mater. 283 (2015) 591-598. https://doi:10.1016/j.jhazmat.2014.10.011.

[35] S.P.F. Costa, P.C.A.G. Pinto, R.A.S. Lapa, M.L.M.F.S. Saraiva, Toxicity assessment of ionic liquids with Vibrio fischeri: an alternative fully automated methodology, J. Hazard Mater. 284 (2015) 136142. https://doi:10.1016/j.jhazmat.2014.10.049.

[36] M.G. Montalbán, J.M. Hidalgo, M. Collado-González, F.G. Díaz Baños, G. Víllora, Assessing chemical toxicity of ionic liquids on Vibrio fischeri: correlation with structure and composition. Chemosphere 155 (2016) 405-414. https://doi:10.1016/j.chemosphere.2016.04.042.

[37] O.B. Ghanem, N. Papaiconomou, M.I. Abdul Mutalib, S. Viboud, M. El-Harbawi, Y. Uemura, G. Gonfa, M.A. Bustam, J.M. Leveque, Thermophysical properties and acute toxicity towards green algae and Vibrio fischeri of amino acid-based ionic liquids, J. Mol. Liq. 212 (2015) 352-359. https://doi:10.1016/j.molliq.2015.09.017.

[38] F. Yan, Q. Shang, S. Xia, Q. Wang, P. Ma, Topological study on the toxicity of ionic liquids on Vibrio fischeri by the quantitative structure-activity relationship method. J. Hazard Mater. 286 (2015) 410415. https://doi:10.1016/j.jhazmat.2015.01.016. 
[39] C. Pretti, C. Chiappe, I. Baldetti, S. Brunini, G. Monni, L. Intorre, Acute toxicity of ionic liquids for three freshwater organisms: Pseudokirchneriella subcapitata, Daphnia magna and Danio rerio, Ecotoxicol. Environ. Saf. 72 (2009) 1170-1176. https://doi.org/10.1016/j.ecoenv.2008.09.010.

[40] A. Wang, L. Chen, D. Jiang, H. Zeng, Z. Yan, Vegetable oil-based ionic liquid microemulsion biolubricants: effect of integrated surfactants, Ind. Crops Prod. 62 (2014) 515-521. https://doi.org/10.1016/j.indcrop.2014.09.031.

[41] P. Nagendramma, S. Kaul, Development of ecofriendly/biodegradable lubricants: an overview, Renew. Sustain. Energy Rev. 16 (2012) 764-774. https://doi.org/10.1016/j.rser.2011.09.002.

[42] A.Z. Syahir, N.W.M. Zulkifli, H.H. Masjuki, M.A. Kalam, A. Alabdulkarem, M. Gulzar, L.S. Khuong, M.H. Harith, A review on bio-based lubricants and their applications, J. Clean. Prod. 168 (2017) 9971016. https://doi.org/10.1016/j.jclepro.2017.09.106.

[43] A. Mezzetta, L. Guazzelli, M. Seggiani, C.S. Pomelli, M. Puccini, C. Chiappe, A general environmentally friendly access to long chain fatty acid ionic liquids (LCFA-ILs), Green Chem. 19 (2017) 3103-3111. https://doi.org/10.1039/c7gc00830a.

[44] C.J. Reeves, S. Garvey, P.L. Menezes, M. Dietz, T.C. Jen, M.R. Lovell, Tribological performance of environmentally friendly ionic liquid lubricants, Am. Soc. Mech. Eng. Tribol. Div. TRIB. (2012) 355357. https://doi.org/10.1115/IJTC2012-61180.

[45] M.A.A. Rocha, A. Van Den Bruinhorst, W. Schröer, B. Rathke, M.C. Kroon, Physicochemical properties of fatty acid based ionic liquids, J. Chem. Thermodyn. (2016). https://doi.org/10.1016/j.jct.2016.04.021.

[46] D. Blanco, N. Rivera, P. Oulego, M. Díaz, R. González, A.H. Battez, Novel fatty acid anion-based ionic liquids : Contact angle, surface tension, polarity fraction and spreading parameter, J. Mol. Liq. 288 (2019) 110995. https://doi.org/10.1016/j.molliq.2019.110995.

[47] S.P.F. Costa, A.M.O. Azevedo, P.C.A.G. Pinto, M.L.M.F.S. Saraiva, Environmental impact of ionic liquids: recent advances in (eco)toxicology and (bio)degradability, Chem. Sus. Chem. 10(10) (2017) 2321-2347. https://doi.org/10.1002/cssc.201700261.

[48] D. Parmentier, S.J. Metz, M.C. Kroon, Tetraalkylammonium oleate and linoleate based ionic liquids: promising extractants for metal salts, Green Chem. 15(1) (2013) 205-209. https://doi.org/10.1039/C2GC36458A. 
[49] R. Gusain, S. Dhingra, O.P. Khatri, Fatty-acid-constituted halogen-free ionic liquids as renewable, environmentally friendly, and high-performance lubricant additives, Ind. Eng. Chem. Res. 55(4) (2016) 856-865. https://doi.org/10.1021/acs.iecr.5b03347.

[50] R. Gusain O.P. Khatri, Fatty acid ionic liquids as environmentally friendly lubricants for low friction and wear, RSC Adv. 6(5) (2016) 3462-3469. https://doi.org/10.1039/C5RA25001C.

[51] N. Rivera, D. Blanco, J.L. Viesca, A. Fernández-González, R. González, A.H. Battez, Tribological performance of three fatty acid anion-based ionic liquids (FAILs) used as lubricant additive. J. of Mol. Liq. 296 (2019) 111881. https://doi.org/10.1016/j.molliq.2019.111881.

[52] M. Fan, L. Ma, C. Zhang, Z. Wang, J. Ruan, M. Han, Y. Ren, C. Zhang, D. Yang, F. Zhou, W. Liu, Biobased green lubricants: physicochemical, tribological and toxicological properties of fatty acid ionic liquids, Trib. Trans. 61(2) (2017) 195-206. https://doi.org/10.1080/10402004.2017.1290856.

[53] P.K. Khatri, M.S. Aathira, G.D. Thakre, S.L. Jain, Synthesis and tribological behavior of fatty acid constituted tetramethylguanidinium (TMG) ionic liquids for a steel/steel contact, Mater. Sc. Eng. C 91 (2018) 208-217. https://doi.org/10.1016/j.msec.2018.05.038.

[54] G. Zheng, T. Ding, Y. Huang, L. Zheng, T. Ren, Fatty acid based phosphite ionic liquids as multifunctional lubricant additives in mineral oil and refined vegetable oil, Tribol. Int. 123 (2018) 316-324. https://doi.org/10.1016/J.TRIBOINT.2018.03.028.

[55] A. Khan, R. Gusain, M. Sahai, O.P. Khatri, Fatty acids-derived protic ionic liquids as lubricant additive to synthetic lube base oil for enhancement of tribological properties, J. Mol. Liq. 293 (2019) 111444. https://doi.org/10.1016/J.MOLLIQ.2019.111444.

[56] N. Rivera, A. García, A. Fernández-González, D. Blanco, R. González, A.H. Battez, Tribological behavior of three fatty acid ionic liquids in the lubrication of different material pairs. J. Mol. Liq. 296 (2019) 111881. https://doi.org/10.1016/j.molliq.2019.111858.

[57] T. Espinosa, J. Sanes, A.E. Jiménez, M.D. Bermúdez, Surface interactions, corrosion processes and lubricating performance of protic and aprotic ionic liquids with OFHC copper, Appl. Surf. Sci. 273 (2013) 578-597. doi:10.1016/j.apsusc.2013.02.083.

[58] D. Blanco, J.L. Viesca, M.T. Mallada, B. Ramajo, R. González, A.E. Battez, Wettability and corrosion of $\left[\mathrm{NTf}_{2}\right]$ anion-based ionic liquids on steel and PVD (TiN, CrN, ZrN) coatings. Surface and Coatings Technology 302 (2016) 13-21. https://doi.org/10.1016/j.surfcoat.2016.05.051. 
[59] A. Khan, R. Gusain, O.P. Khatri, Organophosphate anion based low viscosity ionic liquids as oilmiscible additives for lubrication enhancement, J. Mol. Liq. 272 (2018) 430-438. https://doi.org/10.1016/j.molliq.2018.09.113.

[60] G. Socrates, Infrared Characteristic Group Frequencies: Tables and Charts, 3rd edition, Wiley, New York, 2001.

[61] C.H. Cheah, C.Y. May, Z. Zakaria, R. Daik, Synthesis of palmitic acid-based esters and their effect on the pour point of palm oil methyl esters, Journal of Oil Palm Research 20 (2008) 542-547.

[62] S. Zhang, N. Sun, X. He, X. Lu, X. Zhang, Physical properties of ionic liquids: database and evaluation, J. Phys. Chem. Ref. Data 35 (2006) 1475-1517. https://doi.org/10.1063/1.2204959.

[63] G.Yu, D. Zhao, L. Wen, S. Yang, X. Chen, Viscosity of Ionic Liquids: Database, Observation, and Quantitative Structure-Property Relationship Analysis, AIChE Journal, 58 (9) (2012) 2885-2899. https://doi.org/10.1002/aic.12786.

[64] A.H. Battez, N. Rivera, D. Blanco, P. Oulego, J.L. Viesca, R. González, Physicochemical, traction and tribofilm formation properties of three octanoate-, laurate- and palmitate-anion based ionic liquids, J. Mol. Liq., 284 (2019) 639-646. https://doi.org/10.1016/j.molliq.2019.04.050.

[65] R. Gusain, S. Panda, P.S. Bakshi, R.L. Gardas, O.P. Khatri, Thermophysical properties of trioctylalkylammonium bis(salicylate)borate ionic liquids: effect of alkyl chain length, J. Mol. Liq. 269 (2018) 540-546. https://doi.org/10.1016/j.molliq.2018.08.083.

[66] N. Saurin, I. Minami, J. Sanes, M.D. Bermudez, Study of the effect of tribo-materials and surface finish on the lubricant performance of new halogen-free ionic liquids, Appl. Surf. Sci. 366 (2016) 464-474. https://doi.org/10.1016/j.apsusc.2016.01.127.

[67] P. Oulego, J. Faes, R. González, J.L. Viesca, D. Blanco, A.H. Battez, Relationships between the physical properties and biodegradability and bacteria toxicity of fatty acid-based ionic liquids. J. Mol. Liq., 292 (2019) 111451. https://doi.org/10.1016/j.molliq.2019.111451.

[68] J. Kestin, H. E. Khalifa, W. A. Wakeham, The viscosity of five gaseous hydrocarbons, J. Chem. Phys. 66 (1977) 1132. https://doi.org/10.1063/1.434048

[69] C.J. Reeves, P.L. Menezes, T.C. Jen, M.R. Lovell, The influence of fatty acids on tribological and thermal properties of natural oils as sustainable biolubricants, Tribology International 90 (2015) 123134. doi:10.1016/j.triboint.2015.04.021. 